\title{
Pojęcie nieruchomości rolnej, gospodarstwa rolnego i działalności rolniczej w ustawie o kształtowaniu ustroju rolnego - wybrane kwestie z praktyki notarialnej
}

\section{Wprowadzenie}

Istotnymi pojęciami z zakresu nauki prawa rolnego są: nieruchomość rolna, gospodarstwo rolne oraz działalność rolnicza ${ }^{1}$. Ich definicje zawarto $\mathrm{w}$ różnych aktach prawnych, np. w Kodeksie cywilnym ${ }^{2}$ czy ustawie z 11 kwietnia 2003 r. o kształtowaniu ustroju rolnego ${ }^{3}$. Są one ważne nie tylko dla teorii, lecz także dla praktyki, zwłaszcza w aspekcie czynności notarialnych, np. umowy sprzedaży czy darowizny prawa własności lub użytkowania wieczystego nieruchomości rolnych. Przesądzają bowiem np. o tym, czy zastosowanie ma ustawa z 11 kwietnia 2003 r. o kształtowaniu ustroju rolnego, czy prawo pierwokupu przysługuje KOWR albo Lasom Państwowym (gdy nieruchomość składa się z lasu i działki rolnej) albo jakie obowiązki ma nabywca nieruchomości rolnych po przeniesieniu własności nieruchomości rolnej.

${ }^{1}$ R. Budzinowski, Prawo rolne, jego przedmiot i definicja, w: P. Czechowski (red.), Prawo rolne, Warszawa 2019, s. 32 i n., P. Wojciechowski, Pojęcie nieruchomości rolnej, M. Korzycka, P. Wojciechowski, Pojęcie gospodarstwa rolnego i gospodarstwa rodzinnego w: M. Korzycka (red.), Instytucje prawa rolnego, Warszawa 2019, s. 147 i n.

2 T.j. Dz.U. z 2019 r., poz. 1145 ze zm.

3 T.j. Dz.U. z 2019 r., poz. 1362 ze zm., dalej jako: ustawa o kształtowaniu ustroju rolnego, ustawa z 11 kwietnia 2003 r. albo u.k.u.r. 
Zagadnienia związane z nieruchomościami rolnymi ${ }^{4}$, gospodarstwem rolnym oraz działalnością rolniczą są stosunkowo często poruszane w literaturze ${ }^{5}$. Niewiele jest jednak opracowań, które podejmują tę problematykę, uwzględniając nowelizację ustawy o kształtowaniu ustroju rolnego z 26 kwietnia 2019 r. ${ }^{6}$ i dodatkowo ujmując ją w kontekście praktyki notarialnej.

Celem artykułu jest rozstrzygnięcie problemów interpretacyjnych związanych z pojęciem nieruchomości rolnej, gospodarstwa rolnego, działalności rolniczej w ustawie o kształtowaniu ustroju rolnego przy dokonywaniu czynności notarialnych na przykładzie wybranych zagadnień, zwłaszcza tych związanych z nowelizacją u.k.u.r. z 26 kwietnia 2019 r.

\section{Pojęcie nieruchomości rolnej}

Nieruchomością rolną w świetle u.k.u.r. ${ }^{7}$ jest nieruchomość rolna w rozumieniu Kodeksu cywilnego, z wyłączeniem nieruchomości położonych na obszarach przeznaczonych w planach zagospodarowania przestrzennego na cele inne niż rolne. Według art. $46^{1}$ k.c. nieruchomościami rolnymi (gruntami rolny-

${ }^{4} \mathrm{~K}$. Czerwińska-Koral, Zasady obrotu nieruchomościami rolnymi $w$ postępowaniach sqdowych po 29.04.2016 r. - wybrane zagadnienia praktyki sądowej. Część 1 i część 2, „Przegląd Sądowy” 2018, nr 9, s. 75-88; eadem, Pojęcie nieruchomości rolnej jako wyznacznik zasad obrotu nieruchomościami rolnymi, „Rejent” 2016, nr 6, s. 52-73; K. Marciniuk, Prawne instrumenty ingerencji władzy publicznej w obrót nieruchomościami rolnymi jako środek ksztattowania ustroju rolnego, Białystok 2019, s. 76 i n.; W. Fortuński, M. Kupis, Pojęcie nieruchomości rolnej i gospodarstwa rolnego z uwzględnieniem wybranego orzecznictwa, „Nowy Przegląd Notarialny” 2019, nr 2, s. 37-50; J. Pisuliński, O niektórych osobliwościach obrotu nieruchomościami rolnymi, „Rejent” 2016, nr 5, s. 24, 33; B. Wierzbowski, Pojęcie nieruchomości rolnej w prawie polskim, „Studia Iuridica Agraria” 2005, t. IV, s. 96 i n.

5 R. Budzinowski, Prawne pojęcie działalności rolniczej, „Prawo i Administracja” 2003, s. 167; idem, Nowa definicja przedsiębiorcy rolnego we włoskim kodeksie cywilnym, „Studia Iuridica Agraria" 2002, t. III; idem, Problemy ogólne prawa rolnego. Przemiany podstaw legislacyjnych i koncepcji doktrynalnych, Poznań 2008; idem, Zmiany prawa rolnego. Tendencje rozwoju, „Ruch Prawniczy, Ekonomiczny i Socjologiczny” 2002, nr 2. Na temat działalności rolniczej np. A. Lichorowicz, Przedsiębiorstwo handlowe a przedsiębiorstwo rolne we wtoskim kodeksie cywilnym, w: Ksiega pamiatkowa ku czci Profesora Janusza Szwaji. Prace z wynalazczości i ochrony własności intelektualnej, Kraków 2004, s. 241 i n.; B. Jeżyńska, Status produkcji rolnej w systemie działalności gospodarczej, http://www.ksow.pl/.../Dr_hab._Beata_Jeżyńska_prof. nadzw._-_Status_produkcji_rolnej.doc [dostęp: 10.10.2019]; A. Suchoń, Jeszcze o pojęciu dziatalności rolniczej, „Rejent” 2017, nr 12.

${ }^{6}$ Ustawa z 26 kwietnia 2019 r. o zmianie ustawy o kształtowaniu ustroju rolnego oraz niektórych innych ustaw, Dz.U. poz. 1080 ze zm. Zob. np. J. Bieluk, Ustawa o ksztaltowaniu ustroju rolnego. Komentarz, Warszawa 2019; D. Łobos-Kotowska, M. Stańko, Ustawa o ksztattowaniu ustroju rolnego. Komentarz, Warszawa 2020.

7 J. Bieluk, Ustawa o kształtowaniu ustroju.., s. 12 i n. 
mi) są nieruchomości, które są lub mogą być wykorzystywane do prowadzenia działalności wytwórczej w rolnictwie w zakresie produkcji roślinnej i zwierzęcej, nie wyłączając produkcji ogrodniczej, sadowniczej i rybnej ${ }^{8}$. $Z$ definicji tej, zawartej w Kodeksie cywilnym, wynika, że do uznania nieruchomości za rolną wystarcza sama możliwość wykorzystywania jej na cele szeroko rozumianej działalności rolniczej9. Jak słusznie podkreślił A. Lichorowicz, dla kwalifikacji nieruchomości jako rolnej, decydujące są

czysto agronomiczne cechy gruntu, z których wynika, że uzyskiwanie na nim produktów rolnych jest fizycznie możliwe. Co więcej, uzyskiwanie z gruntu płodów rolnych nie musi stanowić faktu ${ }^{10}$.

Powstaje pytanie o relację pojęć nieruchomości rolnej i gruntu rolnego. $\mathrm{W}$ świetle kodeksu cywilnego są to synonimy, co wynika z art. $46^{1}$ k.c. ${ }^{11}$ Natomiast odrębne definicje gruntu rolnego zawarte zostały w innych aktach prawnych. Przykładem jest chociażby ustawa z 3 lutego 1995 r. o ochronie gruntów rolnych i leśnych ${ }^{12}$. Według zamieszczonej $\mathrm{w}$ niej definicji gruntami rolnymi w rozumieniu ustawy są grunty m.in. określone w ewidencji gruntów jako użytki rolne; pod wchodzącymi w skład gospodarstw rolnych budynkami mieszkalnymi oraz innymi budynkami i urządzeniami służącymi wyłącznie produkcji rolniczej oraz przetwórstwu rolno-spożywczemu; pod budynkami i urządzeniami służącymi bezpośrednio do produkcji rolniczej uznanej za dział specjalny, stosownie do przepisów o podatku dochodowym od osób fizycznych i podatku dochodowym od osób prawnych. Warto także zaznaczyć, że u.k.u.r. w art. 2 wskazuje, że pod pojęciem użytków rolnych należy rozumieć grunty orne, sady, łąki trwałe, pastwiska trwałe, grunty rolne zabudowane, grunty pod stawami i grunty pod rowami.

Dla notariusza istotne jest także pojęcie gruntu rolnego z tego aktu prawnego, w przypadku chociażby przeniesienia własności zabudowanych nieruchomości rolnych, tzw. siedlisk. Po wejściu w życie nowelizacji z 26 kwietnia 2019 r. nadal ma bowiem zastosowanie wyłącznie u.k.u.r. wynikające $\mathrm{z}$ art. 11 ustawy z 14 kwietnia 2016 r. o wstrzymaniu sprzedaży nieruchomości Zaso-

${ }^{8}$ A. Lichorowicz, Glosa do wyroku SN z 2.06.2000 r. II CKN 1067/98, OSP 2001, nr 2, poz. 27 , s. 88 i n.

${ }^{9}$ Uchwała SN z 14.12.1984 r., III CZP 78/84, OSN 1985/10, poz. 149; postanowienie SN z 28.01.1998 r., III CKN 140/98, LEX nr 50652; wyrok SN z 2.06.2000 r., II CKN 1067/98, OSP 2001/2, poz. 27; wyrok SN z 14.11.2001 r., II CKN 440/01, OSN 2002/7-8, poz. 99; E. Gniewek w: E. Gniewek (red.), Kodeks cywilny. Komentarz, Warszawa 2011, s. 129 i n.

${ }^{10}$ A. Lichorowicz, Glosa..., s. 88 i n.

11 J. Bieluk, Ustawa o ksztattowaniu ustroju, komentarz do art. 2 (pkt 6), Legalis 2019 oraz literatura tam podana.

12 T.j. Dz.U. z 2017 r., poz. 1161 ze zm. 
bu Własności Rolnej Skarbu Państwa ${ }^{13}$. Chodzi o grunty rolne zabudowane, o powierzchni nieprzekraczającej pół hektara, które w dniu wejścia w życie ustawy (30 kwietnia $2016 \mathrm{r}$.) zajęte były pod budynki mieszkalne oraz budynki, budowle i urządzenia niewykorzystywane do produkcji rolniczej, wraz z gruntami do nich przyległymi, umożliwiającymi ich właściwe wykorzystanie oraz zajętymi na urządzenie ogródka przydomowego - jeżeli grunty te tworzą zorganizowaną całość gospodarczą oraz nie zostały wyłączone z produkcji rolnej w rozumieniu ustawy z 3 lutego 1995 r. o ochronie gruntów rolnych i leśnych. W tym przepisie ustawodawca nie posługuje się pojęciem nieruchomości rolnej, ale właśnie gruntu rolnego, odwołując się do wspomnianej już ustawy z 3 lutego $1995 \mathrm{r}$.

Należy podkreślić, że u.k.u.r. nie stosuje się w odniesieniu do nieruchomości rolnych w świetle k.c., położonych na obszarach przeznaczonych w planach zagospodarowania przestrzennego na cele inne niż rolne ${ }^{14}$. Sąd Najwyższy w wyroku z 5 września 2012 r. ${ }^{15}$, orzekł, że

nie są nieruchomościami rolnymi w rozumieniu art. 2 pkt 1 ustawy z 2003 r. o kształtowaniu ustroju rolnego nieruchomości, które odpowiadają wymaganiom przewidzianym art. $46^{1}$ k.c., ale w planie zagospodarowania przestrzennego przeznaczone zostały na inne cele niż rolne.

Podobnie w postanowieniu z 18 kwietnia 2019 r. Sąd Najwyższy - Izba Cywilna stwierdza, że

w rozumieniu art. 2 pkt 1 ustawy z 2003 r. o kształtowaniu ustroju rolnego nie są nieruchomościami rolnymi takie, które są wprawdzie takimi w znaczeniu przyjętym $\mathrm{w}$ art. $46^{1}$ k.c., lecz w planach zagospodarowania przestrzennego są przeznaczone na inne cele niż rolne ${ }^{16}$.

\section{Z. Truszkiewic ${ }^{17}$ uważa, że}

sama zmiana przeznaczenia nieruchomości rolnej w MPZP na cele inne niż rolne nie zmienia w ramach k.c. charakteru takiej nieruchomości, gdyż wciąż może być ona wykorzystywana do prowadzenia działalności wytwórczej w rolnictwie. Jednak w kontek-

${ }^{13}$ Ustawa z 14 kwietnia 2016 r. o wstrzymaniu sprzedaży nieruchomości Zasobu Własności Rolnej Skarbu Państwa oraz o zmianie niektórych ustaw, Dz.U. poz. 585 ze zm.

${ }_{14}$ Zob. szerzej Z. Truszkiewicz, Wplyw planowania przestrzennego na pojęcie nieruchomości rolnej w rozumieniu Kodeksu cywilnego, „Studia Iuridica Agraria” 2007, t. VI, s. 147-149; K. Marciniuk, Pojęcie nieruchomości rolnej jako przedmiotu reglamentacji obrotu własnościowego, „Studia Iuridica Lublinensia” 2017, t. XXVI, nr 1, s. 94 i n.

15 IV CSK 93/12, Legalis nr 537348.

${ }^{16}$ IV CSK 464/18, Legalis nr 1898276.

17 Z. Truszkiewicz, Wplyw planowania przestrzennego..., s. 147. 
ście UKUR kwestia ta została wyraźnie uregulowana przez ustawodawcę przez wyłączenie z definicji nieruchomości rolnej, objętej ustawą nieruchomości, położonych na obszarach przeznaczonych w miejscowych planach zagospodarowania przestrzennego na cele inne niż rolne ${ }^{18}$.

Jak słusznie podkreśla autor, ustawodawca, tworząc ów wyjątek od stosowania UKUR, odwołujący się do ustaleń planistycznych, potwierdził, że tego rodzaju grunty nie powinny już podlegać ustawie o kształtowaniu ustroju rolnego, mimo iż plan nie obliguje do zmiany sposobu zagospodarowania, czyli nadal może być wykorzystywany rolniczo ${ }^{19}$.

Warto zaznaczyć, że po zmianie przeznaczenia gruntu rolnego w planie miejscowym właściciel może wystąpić z wnioskiem do starosty o wyłączenie gruntów rolnych z produkcji rolnej lub w niektórych przypadkach rozpocząc inne niż rolne użytkowanie gruntów nawet bez decyzji (art. 11, 12 ustawy o ochronie gruntów rolnych i leśnych). Z kolei art. 35 ustawy z 27 marca 2003 r. o planowaniu i zagospodarowaniu przestrzennym ${ }^{20}$ określa, że tereny, których przeznaczenie zmienia plan miejscowy, mogą być wykorzystywane tak jak dotąd do czasu ich zagospodarowania zgodnie z tym planem, chyba że w planie ustalono inaczej. Naczelny Sąd Administracyjny w Warszawie w wyroku z 8 października 2015 r. ${ }^{21}$ orzekł, że

jeżeli w planie miejscowym nie zawarto postanowień określających wykorzystanie danych terenów do czasu ich zagospodarowania zgodnie z tym planem, wówczas tereny te mogą być z mocy art. 35 powołanej wyżej ustawy wykorzystane w dotychczasowy sposób $^{22}$.

Może się jednak zdarzyć, że w planie ustalono inny niż rolniczy sposób ich tymczasowego zagospodarowania. Wtedy pojawia się problem związany z obowiązkiem prowadzenia działalności rolniczej przez pięć lat. W praktyce notarialnej powstała wątpliwość, czy osoba, która nabyła nieruchomość rolną (np. 2 ha) i w świetle przepisów ma obowiązki wynikające z u.k.u.r., jest na-

${ }^{18}$ Ibidem.

${ }^{19}$ Ibidem. Referat i wypowiedzi Z. Truszkiewicza w czasie panelu dyskusyjnego na konferencji naukowej „Ustawa o kształtowaniu ustroju rolnego w teorii i praktyce” na Wydziale Prawa i Administracji UAM, Poznań, 20 listopada 2019 r.

${ }^{20}$ T.j. Dz.U. z 2016, poz. 778 ze zm., zwana ustawą o planowaniu i zagospodarowaniu przestrzennym.

${ }^{21}$ II OSK 451/14, LEX nr 2108528.

${ }^{22}$ LEX nr 2108528; J. Grykiel, Ograniczenia obrotu nieruchomościami rolnymi oraz prawami udziałowymi w spótkach po nowelizacji ustawy o ksztaltowaniu ustroju rolnego, „Monitor Prawniczy" 2016, nr 12. 
dal zobowiązana do ich realizacji, skoro nastąpiła zmiana w planie zagospodarowania przestrzennego. $Z$ jednej strony narzuca się interpretacja, że gdy nieruchomości zostaną przeznaczone na cele inne niż rolne, właściciel nie ma już obowiązku prowadzenia gospodarstwa rolnego na tych gruntach i może je swobodnie zbywać, nawet jeżeli nie minął pięcioletni okres prowadzenia gospodarstwa rolnego. Inną wykładnię przyjęło Ministerstwo Rolnictwa i Rozwoju Wsi oraz Krajowy Ośrodek Wsparcia Rolnictwa; zgodnie z nią producent rolny do upływu 5-letniego okresu od nabycia nieruchomości rolnej objęty jest obowiązkami z u.k.u.r. ${ }^{23}$ Przedstawiciele tych instytucji podczas konferencji naukowej 20 listopada 2019 r. na Wydziale Prawa i Administracji UAM w Poznaniu stwierdzili, że

zmiana przeznaczenia nieruchomości dokonanej w okresie późniejszym, tj. po nabyciu, nie powoduje automatycznego uchylenia ograniczenia we wcześniejszym zbyciu takiej nieruchomości lub oddaniu jej w posiadanie innym podmiotom ${ }^{24}$.

Notariusz zatem przed sporządzeniem aktu notarialnego powinien sprawdzić, czy dana nieruchomość w momencie nabycia przez zbywcę objęta była reżimem u.k.u.r. Jeśli tak, to - według MRiRW - Krajowy Ośrodek Wsparcia Rolnictwa musi wyrazić zgodę na jej zbycie.

Po zmianie przeznaczenia nieruchomości rolnej w planie miejscowym może być ona nadal wykorzystywana do prowadzenia działalności wytwórczej w rolnictwie. Jeśli jednak w planie ustalono inny niż rolniczy sposób tymczasowego zagospodarowania nieruchomości, to właściciel nie może dalej prowadzić działalności rolniczej na tych gruntach. Pojawia się także pytanie o relację ewentualnego obowiązkowego stosowania u.k.u.r. (po zmianie planu miejscowego) do nieruchomości, które już nie są rolne w świetle wspomnianej ustawy, do ogólnej zasady wynikającej z analizowanego aktu prawnego. Ustawa ta ma zastosowanie tylko do nieruchomości rolnych w rozumieniu Kodeksu cywilnego, z wyłączeniem tych położonych na obszarach przeznaczonych $\mathrm{w}$ planach zagospodarowania przestrzennego na cele inne niż rolne. Ustawa nie wskazuje, czy jej postanowienia nadal należy stosować w przypadku nieruchomości, które miały charakter rolny przed zmianą planu miejscowego, czy tylko do obowiązków właściciela/nabywcy tych gruntów.

${ }^{23}$ Wypowiedzi przedstawicieli MRiRW i KOWR w czasie panelu dyskusyjnego na konferencji naukowej „Ustawa o kształtowaniu ustroju rolnego w teorii i praktyce” na Wydziale Prawa i Administracji UAM, Poznań, 20 listopada 2019 r. Zob. też Często zadawane pytania, http:// www.kowr.gov.pl/ukur/zgody-na-nabycie-nieruchomosci-rolnych/czesto-zadawane-pytania [dostęp: 30.11.2019].

${ }^{24}$ Ibidem. 
Jeżeli taka była wola ustawodawcy, to powstaje wątpliwość, dlaczego nie ma stosownej regulacji prawnej, rozstrzygającej tę kwestię w u.k.u.r.? Jednocześnie z uwagi na opłatę planistyczną ${ }^{25}$, którą musi z reguły uiścić na rzecz gminy sprzedający grunty rolne - w przypadku zawarcia umowy sprzedaży w ciągu 5 lat od zmiany ich przeznaczenia w planie miejscowym - niewielu właścicieli zawiera takie kontrakty w tym czasie. Nie ulega wątpliwości, że ustawa o planowaniu i zagospodarowaniu przestrzennym powinna gwarantować większą ochronę gruntów.

W praktyce notarialnej pojawia się także dylemat, gdy nieruchomość przeznaczona jest $\mathrm{w}$ planie zagospodarowania przestrzennego $\mathrm{w}$ części na cele rolne, a w części na inne ${ }^{26}$. Zgodnie ze stanowiskiem Krajowej Rady Notarialnej, uzgodnionym z Agencją Nieruchomości Rolnych, w sprawie stosowania w praktyce notarialnej ustawy o kształtowaniu ustroju rolnego ${ }^{27}$ nieruchomościami rolnymi są nieruchomości w rozumieniu Kodeksu cywilnego, z wyłączeniem nieruchomości przeznaczonych $\mathrm{w}$ planie zagospodarowania przestrzennego (w całości) na cele inne niż rolne. Oznacza to, że w przypadku, gdy tylko część (nawet niewielka) przeznaczona jest na cele inne niż rolne, u.k.u.r. ma zastosowanie. Zgodnie z tym stanowiskiem

Ustawa dotyczy zarówno nieruchomości zabudowanych, jak i niezabudowanych. Zakresem ustawy nie są objęte nieruchomości, które ze względu na ich charakter nie są lub nie mogą być wykorzystywane na cele rolne, np. nieruchomości lokalowe, a także nieruchomości zabudowane budynkami mieszkalnymi, innymi budynkami, budowlami i urządzeniami niewykorzystywanymi do produkcji rolniczej - wraz z gruntami do nich przyległymi umożliwiającymi ich właściwe wykorzystanie, drogi wewnętrzne, nieruchomości znajdujące się pod parkami i ogrodami wpisanymi do rejestru zabytków ${ }^{28}$.

${ }^{25}$ Zob. art. 36 ust. 4 ustawy z 27 marca 2003 r. o planowaniu i zagospodarowaniu przestrzennym (t.j. Dz.U. z 2020 r., poz. 293 ze zm.), który określa, że jeśli w związku z uchwaleniem planu miejscowego albo jego zmianą wartość nieruchomości wzrosła, a właściciel lub użytkownik wieczysty zbywa tę nieruchomość, to wójt, burmistrz albo prezydent miasta pobiera jednorazową opłatę ustaloną $\mathrm{w}$ tym planie, określoną $\mathrm{w}$ stosunku procentowym do wzrostu wartości nieruchomości. Opłata ta jest dochodem własnym gminy. Wysokość opłaty nie może być wyższa niż 30\% wzrostu wartości nieruchomości. Ustawa stanowi, że roszczenie można zgłaszać w terminie 5 lat od dnia, w którym plan miejscowy albo jego zmiana stały się obowiązujące.

${ }_{26}$ Zob. szerzej W. Pańko, Własność gruntowa w planowanej gospodarce przestrzennej. Studium prawne, Katowice 1978, s. 139 i n. oraz literatura tam wskazana.

${ }^{27}$ Stanowisko KRN, http://www.anr.gov.pl/web/guest/stanowisko-krajowej-rady-notarialnej-i-agencji-nieruchomosci-rolnych-ukur [dostęp: 10.11.2016].

${ }^{28}$ Ibidem. 
Sąd Najwyższy - Izba Cywilna w wyroku z 5 września 2012 r. ${ }^{29}$ orzekł, że

nieruchomością rolną w rozumieniu art. 2 pkt 1 ustawy z 11 kwietnia 2003 r. o kształtowaniu ustroju rolnego jest także nieruchomość częściowo przeznaczona w planach zagospodarowania przestrzennego na cele inne niż rolne ${ }^{30}$.

Również przedstawiciele MRiRW i KOWR podczas konferencji 20 listopada 2020 r. podkreślali, że przepisy u.k.u.r. dotyczą nieruchomości mieszanych, czyli takich, których rolna jest tylko część.

Sytuacja jest dla notariusza bardziej skomplikowana, gdy nie uchwalono planu zagospodarowania przestrzennego. W takim przypadku należy odwołać się do definicji nieruchomości rolnej zawartej w Kodeksie cywilnym ${ }^{31}$. $\mathrm{Z}$ art. $46^{1}$ k.c. wynika istnienie potencjalnej perspektywy uzyskiwania z gruntu płodów rolnych, co znajduje uzasadnienie w fizyczno-agronomicznych właściwościach gruntu ${ }^{32}$. O rolniczym charakterze gruntu przesądzają rolnicze właściwości gruntu, a nie sposób aktualnego wykorzystywania ${ }^{32}$. R. Budzinowski zaakcentował, że istotne są właściwości fizyko-chemiczne (agronomiczne) wierzchniej warstwy gleby, pozwalające na uzyskiwanie płodów rolnych po zastosowaniu odpowiednich zabiegów agrotechnicznych (chodzi o czysto agronomiczne cechy gruntu, które powodują, że uzyskiwanie z niego produktów rolnych jest fizycznie możliwe) $)^{33}$.

Stanowisko Krajowej Rady Notarialnej uzgodnione z Agencją Nieruchomości Rolnych jest takie, że przy kwalifikowaniu nieruchomości jako rolnej

${ }^{29}$ IV CSK 93/12, LEX nr 1229816.

${ }^{30}$ Opubl. Biuletyn SN-IC 2013/10.

31 B. Wierzbowski, Pojęcie nieruchomości rolnej w prawie polskim, „Studia Iuridica Agraria” 2005, t. IV, s. 95; E. Gniewek, objaśnienia do art. $46^{1}$ k.c., w: E. Gniewek, P. Machnikowski (red.), Kodeks cywilny. Komentarz, wyd. 8, Warszawa 2017, s. 107; R. Budzinowski, objaśnienia do art. 461 k.c., w: M. Gutowski (red.), Kodeks cywilny, t. I, Komentarz do art. 1-449, Warszawa 2018, s. 436 i n.

${ }^{32}$ Ibidem. A. Lichorowicz, Glosa do wyroku SN z 2.06.2000 r., II CKN 1067/98, s. 88; W.J. Katner, Przedmiot stosunku cywilnoprawnego, w: M. Safjan (red.), System prawa prywatnego, t. I.: Prawo cywilne - część ogólna, Warszawa 2012, s. 1302.

${ }^{33}$ R. Budzinowski, objaśnienia do art. 461 k.c., w: M. Gutowski (red.), Kodeks cywilny, s. 436 i n.; M. Borkowski, Pojęcie ,nieruchomości rolnej” oraz „nieruchomości leśnej” w rozumieniu ustawy o nabywaniu nieruchomości przez cudzoziemców, „Rejent” 2007, nr 7-8, s. 39; G. Bieniek, w: G. Bieniek, S. Rudnicki, Nieruchomości. Problematyka prawna, Warszawa 2009, s. 169; E. Gniewek, w: E. Gniewek (red.), Kodeks cywilny. Komentarz, Warszawa 2011, s. 116; E. Klat-Górska, Ustawa o ksztattowaniu ustroju rolnego. Komentarz, Warszawa 2014, s. 37; E. Skowrońska-Bocian, M. Warciński, w: K. Pietrzykowski (red.), Kodeks cywilny, t. I, Komentarz. Art. 1-44910, Warszawa 2018, s. 236; zob. też uchwała SN z 20 lipca 1995 r., III CZP 88/95, OSN 1995/11/163; uzasadnienie wyroku SN z 14 listopada 2001 r., II CKN 440/01, OSNC 2002/7-8/99; wyrok WSA z 9 kwietnia 2009 r., II SA/Sz 865/08, LEX nr 554853. 
pomocne mogą być dane z ewidencji gruntów i budynków ${ }^{34}$. Można podzielić opinię J. Bieluka, że

trudno jest wymagać od notariusza, aby posiadał wiedzę specjalną z zakresu agronomii i rolnictwa i na jej podstawie dokonywał oceny, czy dany grunt spełnia wymogi pozwalające na prowadzenie z jego wykorzystaniem działalności wytwórczej w rolnictwie, czyli tym samym czy spełnione są wymogi zawarte w art. $46^{1} \mathrm{KC}$, oraz aby przeprowadzał postępowanie dowodowe (...) natomiast w praktyce notariusz dysponuje jedynie danymi wynikającymi z miejscowego planu zagospodarowania przestrzennego lub ewidencji gruntów i budynków, a więc dotyczącymi ich prawnego przeznaczenia ${ }^{35}$.

Nie ulega wątpliwości, że zadaniem notariusza nie jest podejmowanie działań w zakresie badania właściwości wytwórczych gruntów rolnych, będących przedmiotem czynności notarialnych. W niektórych przypadkach, prócz danych z ewidencji gruntów i budynków, istotne może być w akcie notarialnym oświadczenie stron o właściwościach i możliwościach w zakresie wykorzystywania gruntów określonych w ewidencji jako rolne. Przykładowo, grunty znajdujące się pod parkami wpisanymi do rejestru zabytków nie mogą być wykorzystywane na cele działalności wytwórczej w rolnictwie. Nie stanowiąc nieruchomości rolnych w świetle k.c., nie są objęte reżimem u.k.u.r. W takiej sytuacji odpowiednie oświadczenie sprzedającego powinno zostać zawarte w akcie notarialnym.

\section{Pojęcie gospodarstwa rolnego}

Pojęcie „gospodarstwo rolne" ${ }^{36}$ występuje w wielu aktach prawnych ${ }^{37}$. Według ustawy o kształtowaniu ustroju rolnego jest to gospodarstwo rolne w rozumieniu Kodeksu cywilnego, w którym powierzchnia nieruchomości rolnej

${ }^{34}$ Stanowisko KRN, http://www.anr.gov.pl/web/guest/stanowisko-krajowej-rady-notarialnej-i-agencji-nieruchomosci-rolnych-ukur [dostęp: 10.11.2016]; Z. Truszkiewicz, Wpływ planowania przestrzennego na pojęcie nieruchomości rolnej w rozumieniu Kodeksu cywilnego, „Studia Iuridica Agraria" 2007, nr 6, s. 152; D. Łobos-Kotowska, M. Stańko, Ustawa o ksztaltowaniu..., komentarz do art. 2 (pkt 12), LEX. Wyrok NSA z 12 grudnia 2017 r., I OSK 1174/17, „Dane ewidencyjne mają charakter informacyjno-techniczny i odnoszą się do konkretnej działki ewidencyjnej. Ewidencja rejestruje jedynie stany prawne wynikające z określonych dokumentów urzędowych, a zatem stany ustalane w innym trybie lub przez inne uprawnione organy orzekające. Dla obywateli i organów państwowych moc wiążącą mają tylko dane dotyczące opisu gruntów (ich położenia, konturu granic, rodzaju użytków, itp.)”, Lex nr 2430459.

${ }^{35}$ J. Bieluk, Ustawa o ksztattowaniu ustroju..., komentarz do art. 2 (pkt 14), Legalis nr 2019.

${ }^{36}$ Z. Truszkiewicz, Nieruchomość rolna ..., s. 142 i n.

${ }^{37}$ Zob. np. ustawa z 15 listopada 1984 r. o podatku rolnym (t.j. Dz.U. z 2019 r., poz. 1256, 1309). 
albo łączna powierzchnia nieruchomości rolnych jest nie mniejsza niż 1 ha. Od 26 czerwca 2019 r. przepis stanowi, że obszar 1 ha może się odnosić do jednej lub do kilku nieruchomości rolnych łącznie. Powstaje pytanie, czy w skład gospodarstwa rolnego wchodzą wszystkie nieruchomości rolne, czy tylko te w świetle u.k.u.r., czyli przede wszystkim przeznaczone w planie miejscowym na cele rolne. Artykuł $55^{3}$ k.c. stanowi, że za gospodarstwo rolne uważa się grunty rolne wraz z gruntami leśnymi, budynkami lub ich częściami, urządzeniami i inwentarzem, jeżeli stanowią lub mogą stanowić zorganizowaną całość gospodarczą ${ }^{38}$, oraz prawami związanymi z prowadzeniem gospodarstwa rolnego.

W skład gospodarstwa rolnego w świetle Kodeksu cywilnego wchodzą wszystkie grunty, zarówno rolne, jak i te, które według planu zagospodarowania przestrzennego mogą być wykorzystywane na cele inne niż rolne. Powstaje wątpliwość co do sytuacji, gdy wszystkie grunty rolne o powierzchni 5 ha w planie miejscowym przeznaczone są na cele inne niż rolne. Moim zdaniem możliwa jest interpretacja, że gospodarstwem rolnym według u.k.u.r. jest tylko taka jednostka, w której powierzchnia nieruchomości rolnych w świetle u.k.u.r. albo łączna powierzchnia takich nieruchomości rolnych jest nie mniejsza niż 1 ha. Skoro ustawodawca posługuje się pojęciem nieruchomości rolnej, to zasadne byłoby odwołanie się do definicji tego pojęcia z u.k.u.r., zgodnie z ogólną zasadą, że na potrzeby danego aktu prawnego wykorzystuje się definicje w nim zawarte. Warto zaznaczyć, że definicja gospodarstwa rolnego z u.k.u.r. uległa zmianie. W pierwotnej wersji ustawy z 11 kwietnia 2003 r. przyjęto, że jest to gospodarstwo rolne w rozumieniu Kodeksu cywilnego o obszarze nie mniejszym niż 1 ha użytków rolnych.

Na podstawie nowelizacji z 14 kwietnia 2016 r. ,użytki rolne” zostały zastąpione „nieruchomością rolną”. Biorąc jednak pod uwagę wykładnię literalną, należy uznać, że gospodarstwem rolnym w świetle u.k.u.r. jest każde gospodarstwo rolne w rozumieniu Kodeksu cywilnego, w którym powierzchnia nieruchomości rolnej (według k.c.) albo łączna powierzchnia nieruchomości rolnych jest nie mniejsza niż 1 ha. Co do zasady w literaturze prezentowana jest ta druga interpretacja $^{39}$. Zasługuje ona na poparcie, chociaż występuje tu brak powiązania pomiędzy dwoma zasadniczymi pojęciami, a mianowicie nieruchomością

${ }^{38}$ R. Budzinowski, Pojęcie gospodarstwa rolnego wedlug Kodeksu cywilnego (rozważania na tle art. $55^{3}$ k.c.), ,Ruch Prawniczy, Ekonomiczny i Socjologiczny” 1991, nr 3; K. Stefańska, Darowizna gospodarstwa rolnego na rzecz małoletniego, w: Obrót nieruchomościami w praktyce notarialnej, Kraków 1997; eadem, Model indywidualnego gospodarstwa rolnego w świetle znowelizowanego kodeksu cywilnego, „Państwo i Prawo” 1992, nr 3; M. Bednarek, Mienie. Komentarz do art. 44-55(3) Kodeksu cywilnego, Kraków 1997.

39 J. Bieluk, Ustawa o ksztaltowaniu ustroju..., komentarz do art. 2 (Nb VI, pkt 11), Legalis nr 2019; D. Łobos-Kotowska, M. Stańko, Ustawa o ksztaltowaniu ustroju rolnego. Komentarz, 2020, Lex elektr., komentarz do art. 2 pkt II. 
rolną w świetle u.k.u.r. a gospodarstwem rolnym według tej ustawy. Producent rolny, który jest właścicielem nieruchomości rolnych przeznaczonych w planie miejscowym na cele inne niż rolne o powierzchni np. 5 ha, czyli gruntów, które nie są nieruchomościami rolnymi w świetle u.k.u.r., jest właścicielem gospodarstwa rolnego według u.k.u.r. (o ile są to nieruchomości rolne stosownie do k.c.).

Kolejnym problemem dla notariuszy jest ustalenie, czy każda nieruchomość rolna nabywana przez rolnika musi wejść w skład jego gospodarstwa rolnego. Czy możliwe jest nabycie pół hektara gruntów rolnych (np. zabudowanych), które będą funkcjonowały poza prowadzonym gospodarstwem? $\mathrm{Na}$ przykład: rolnik kupuje zabudowaną działkę, którą ma zamiar w przyszłości przekazać dziecku w darowiźnie. Moim zdaniem jest to możliwe, jeżeli nieruchomości nie stanowią bądź nie będą stanowiły zorganizowanej całości gospodarczej. W takim wypadku w akcie notarialnym powinno znaleźć się oświadczenie nabywcy, że co prawda prowadzi gospodarstwo rolne, ale nieruchomość ta nie wejdzie w skład gospodarstwa rolnego ze względu na obiektywne uwarunkowania, np. zabudowę i wykorzystywanie na cele mieszkaniowe czy $\mathrm{z}$ uwagi na nierolniczy charakter, przeznaczenie w planie zagospodarowania przestrzennego, odległość od prowadzonego gospodarstwa.

Dla przeprowadzenia czynności notarialnych ważne jest ustalenie, czy każda nieruchomość rolna, której obszar przekracza hektar, jest traktowana jako gospodarstwo rolne. Podstawowy problem w tym zakresie dotyczy interpretacji sformułowania „stanowią lub mogą stanowić zorganizowaną całość gospodarczą”. Należy podkreślić, że ustawodawca użył słów „stanowią lub mogą stanowić”. Jak zaznaczył R. Budzinowski:

funkcjonalna więź między poszczególnymi materialnymi składnikami gospodarstwa rolnego opiera się na dwóch elementach. $Z$ jednej strony bazuje ona na obiektywnych właściwościach tych składników i ich usytuowaniu względem siebie, z drugiej zaś - na subiektywnym akcie włączenia ich do procesu gospodarowania. Dzięki organizatorskiej działalności podmiotu składniki materialne wchodzą trwale w skład warsztatu rolnego. To właśnie określony podmiot, by zrealizować przyjęty cel ekonomiczny, organizuje (w gospodarstwo rolne) instrumenty swojej działalności ${ }^{40}$.

Sąd Najwyższy - Izba Cywilna w postanowieniu z 5 kwietnia 2017 r. ${ }^{41}$ orzekł, że

Dla przyjęcia, że nieruchomość jest gospodarstwem rolnym w rozumieniu art. 55[3] w zw. z art. 46[1] k.c. nie ma znaczenia to, czy jest ona aktualnie wykorzystywana rolniczo, a jedynie to, że jest gruntem rolnym (lub leśnym) i stanowi lub może stanowić (potencjalnie) zorganizowaną całość gospodarczą.

${ }^{40}$ R. Budzinowski, Pojęcie gospodarstwa rolnego..., s. 60 i n.

${ }^{41}$ II CSK 406/16, LEX nr 2309578. 
Wojewódzki Sąd Administracyjny w Gorzowie Wielkopolskim w wyroku z 28 stycznia $2015 \mathrm{r}^{42}$ stwierdził:

\begin{abstract}
Przyjmując cywilistyczne rozumienie gospodarstwa rolnego, nie można pominąć, iż jednym z jego istotnych elementów jest to, że stanowi pewną zorganizowaną całość gospodarczą. Bez znaczenia natomiast pozostaje okoliczność, czy wchodzące w jego skład grunty są rozproszone, czy też pozostają w zwartym kompleksie. W każdej sprawie konieczne jest dokonanie indywidualnej oceny, jakie gospodarstwo rolne związane jest z planowaną zabudową, czy ta zabudowa pełni funkcję zabudowy zagrodowej dla tego gospodarstwa rolnego oraz jaki jest związek poszczególnych części gospodarstwa rolnego położonych w różnych gminach.
\end{abstract}

Sądzę, że należy uwzględnić kierunek produkcji danego gospodarstwa rolnego i sposób prowadzenia działalności rolniczej. Istnieją bowiem jednostki o charakterze typowo nasiennym, których właściciel może korzystać w uprawie gruntu z pomocy przedsiębiorców zajmujących się usługami agrotechnicznymi bądź odpłatnie zlecać ich wykonywanie osobom fizycznym. W takiej sytuacji w skład gospodarstwa rolnego mogą wchodzić przede wszystkim (albo tylko) grunty rolne. Gdy zachodzi wątpliwość, czy nieruchomości rolne tworzą gospodarstwo rolne, istotne wydaje się oświadczenie producenta rolnego w akcie notarialnym, czy dana jednostka stanowi gospodarstwo rolne w świetle u.k.u.r. Chodzi przede wszystkim o ustalenie, czy składniki stanowią lub mogą stanowić zorganizowaną całość gospodarczą.

Zdarza się, że w ramach jednej księgi wieczystej część nieruchomości ma charakter rolny, a część jest lasem lub rolnik jest właścicielem nieruchomości rolnych i gruntów leśnych. Według art. 37a ustawy z 28 września 1991 r. o lasach ${ }^{43}$ Skarbowi Państwa, reprezentowanemu przez Lasy Państwowe, nie przysługuje z mocy prawa pierwokup ani prawo nabycia gruntu (np. oznaczonego jako las w ewidencji gruntów i budynków) w przypadku zbycia gospodarstwa rolnego, o którym mowa w ustawie z 11 kwietnia 2003 r. o kształtowaniu ustroju rolnego. Ustalenie, że wskazane grunty nie tworzą gospodarstwa rolnego w świetle u.k.u.r., a prawo pierwokupu gruntu z mocy prawa przysługuje kilku podmiotom (w tym KOWR), powoduje, że pierwszeństwo w wykonaniu prawa pierwokupu lasów mają Lasy Państwowe. Główny problem stanowią tu różne interpretacje sformułowania, że składniki gospodarstwa ,stanowią lub mogą stanowić zorganizowaną całość gospodarczą".

\footnotetext{
42 II SA/Go 785/14, LEX nr 1643869.

${ }^{43}$ Dz.U. z 2020 r., poz. 6.
} 


\section{Pojęcie działalności rolniczej}

Z perspektywy dokonywania czynności notarialnych istotne jest również pojęcie działalności rolniczej, związane z gospodarstwem rolnym. Punktem wyjścia rozważań na ten temat może być art. 2a ust. 4 u.k.u.r. Przepis ten określa, że nabycie nieruchomości rolnej za zgodą Dyrektora Generalnego Krajowego Ośrodka (wyrażoną w drodze decyzji administracyjnej, wydanej na wniosek zbywcy nieruchomości rolnej) jest możliwe, jeżeli nabywca nieruchomości rolnej m.in. zobowiąże się do prowadzenia działalności rolniczej na nabywanej nieruchomości rolnej. Wymóg ten dotyczy nieruchomości rolnych o powierzchni co najmniej 1 ha. Według u.k.u.r. pod pojęciem ,prowadzenia działalności rolniczej" należy rozumieć prowadzenie działalności wytwórczej w rolnictwie w zakresie produkcji roślinnej lub zwierzęcej, w tym produkcji ogrodniczej, sadowniczej i rybnej. Podobnie z art. $46^{1}$ k.c. wynika, że działalność wytwórcza obejmuje produkcję roślinną i zwierzęcą, nie wyłączając produkcji ogrodniczej, sadowniczej i rybnej. Działalność rolnicza wytwórcza polega co do zasady na wykorzystywaniu naturalnych właściwości organizmów żywych, roślinnych i zwierzęcych. Niemniej możliwości oddziaływania na przebieg procesów biologicznych są coraz większe ${ }^{44}$.

Inaczej sformułowany jest obowiązek w odniesieniu do nabywców nieruchomości rolnych, bez konieczności uzyskania wspomnianej zgody. Mianowicie według art. $2 \mathrm{~b}$ ustawy o kształtowaniu ustroju rolnego nabywca nieruchomości rolnej jest zobowiązany prowadzić gospodarstwo rolne, w skład którego weszła nabyta nieruchomość rolna, przez okres co najmniej 5 lat od dnia nabycia przez niego tej nieruchomości, a w przypadku osoby fizycznej prowadzić to gospodarstwo osobiście. W tym czasie nieruchomość nie może być ani zbyta, ani oddana w posiadanie innym podmiotom. Artykuł 7 ustawy z 26 kwietnia 2019 r. o zmianie ustawy o kształtowaniu ustroju rolnego określa, że w przypadku nieruchomości rolnych nabytych przed wejściem w życie niniejszej ustawy do okresu, przez który nabywca nieruchomości rolnej, jaka weszła w skład jego gospodarstwa rolnego, jest obowiązany prowadzić to gospodarstwo rolne, oraz okresu, w którym nabyta nieruchomość nie może być zbyta ani oddana $\mathrm{w}$ posiadanie innym podmiotom, stosuje się przepisy ustawy zmienianej w art. 1, w brzmieniu nadanym niniejszą ustawą (czyli 5 lat zamiast 10). Według nowelizacji obowiązek prowadzenia gospodarstwa rolnego przez 5 lat odnosi się także do osób bliskich rolnika, którym przekazał nieruchomości rolne. W praktyce powstał problem, czy ów obowiązek dotyczy także osób

${ }^{44}$ R. Budzinowski, Problemy ogólne prawa rolnego. Przemiany podstaw legislacyjnych i koncepcji doktrynalnych, Poznań 2008, s. 194 i n. 
bliskich, które nabyły grunty przed 26 czerwca 2019 r. Do tego czasu ustawa zwalniała $\mathrm{z}$ obowiązku prowadzenia gospodarstwa rolnego osoby bliskie zbywcy i nie odnosił się do nich zakaz zbywania czy oddawania w posiadanie. Obecnie jest inaczej. Uważam, że zmienione przepisy u.k.u.r. nie stanowią podstawy do nałożenia obowiązków w zakresie prowadzenia gospodarstwa rolnego oraz zakazu zbywania na osoby bliskie, które nabyły nieruchomości rolne przed 26 czerwca 2019 r. bez wymienionych powyżej obowiązków i zakazów (według zasady, że prawo nie działa wstecz - lex retro non agit).

Rodzi się pytanie o związek między działalnością rolniczą a prowadzeniem gospodarstwa rolnego. To pierwsze pojęcie jest szersze, gdyż działalność rolnicza może być wykonywana zarówno w gospodarstwie rolnym, jak i poza nim. Aktywność ta może być zatem prowadzona w jednostce, która $\mathrm{z}$ uwagi na fakt, że jej składniki nie „stanowią lub mogą stanowić” zorganizowanej całości, jej składniki czy powierzchnia mogą nie zostać uznane za gospodarstwo rolne. Oznacza to w praktyce, że np. osoba, która uzyskała zgodę na nabycie 2 ha nieruchomości rolnych, które nie tworzą gospodarstwa rolnego w świetle u.k.u.r., ma obowiązek prowadzenia na nich działalności rolniczej. A zatem czy działalność rolnicza albo prowadzenie gospodarstwa rolnego łączy się z koniecznością zbywania uzyskanych produktów rolnych? Przykładowo: nabywcy nieruchomości rolnych o powierzchni np. 1,5 ha wykorzystują produkty rolne na potrzeby własne i rodziny. Czy w takim przypadku spełniony zostanie obowiązek prowadzenia działalności rolniczej czy gospodarstwa rolnego?

Działalność rolnicza, jeśli jest ukierunkowana na zbyt, czyli na cele zarobkowe ${ }^{45}$, jest działalnością gospodarczą. Istnieją przypadki, w których produkty rolne uzyskane w wyniku uprawy roślin lub hodowli zwierząt (będące efektem działalności rolniczej) nie są zbywane, ale wykorzystywane na cele własne i rodziny ${ }^{46}$. Rozporządzenie ministra rolnictwa i rozwoju wsi z 18 kwietnia 2016 r. w sprawie szczegółowych warunków i trybu przyznawania, wypłaty oraz zwrotu pomocy finansowej w ramach poddziałania „Płatności na rzecz rolników kwalifikujących się do systemu dla małych gospodarstw, którzy trwale przekazali swoje gospodarstwo innemu rolnikowi” objętego Programem Rozwoju Obszarów Wiejskich na lata 2014-202047 określa, że warunek zaprzestania prowadzenia działalności rolniczej uważa się za spełniony, jeżeli po przekazaniu gospodarstwa rolnego łączna powierzchnia gruntów rolnych posiadanych lub współposiadanych przez rolnika i jego małżonka nie przekra-

${ }^{45}$ Ibidem, s. 194 i n.; II OSK 1618/06, LEX nr 364703; R. Budzinowski, Gospodarstwo rolne i przedsiębiorstwo rolne, w: A. Stelmachowski (red.), Prawo rolne, Warszawa 2005, s. 114.

${ }^{46}$ R. Budzinowski, Gospodarstwo rolne i przedsiębiorstwo ..., s. 114. Tak: M.A. Waligórski, Działalność gospodarcza w ujęciu prawa administracyjnego, Poznań 2006, s. 25 i n.

47 Dz.U. poz. 598. 
cza pół hektara, a działalność rolnicza prowadzona na tych gruntach służy wyłącznie zaspokajaniu potrzeb własnych rolnika oraz osób pozostających z nim we wspólnym gospodarstwie domowym. Zatem prowadzenie działalności rolniczej czy gospodarstwa rolnego nie musi łączyć się ze zbytem produktów rolnych.

Pojawia się pytanie, czy obowiązek prowadzenia działalności rolniczej odnosi się także do nieruchomości rolnej o powierzchni poniżej 1 ha. Czytając literalnie art. 2b ustawy z 11 kwietnia 2003 r. o kształtowaniu ustroju rolnego, można przyjąć, że obowiązek prowadzenia działalności rolniczej dotyczy gospodarstwa rolnego, a nie nieruchomości rolnej o takiej powierzchni. Nie ulega wątpliwości, że działalność rolnicza może być prowadzona na nieruchomości o rozmiarze mniejszym niż 1 ha, ale taka sytuacja nie jest objęta obowiązkami na gruncie u.k.u.r. Takie też stanowisko zostało przedstawione przez przedstawicieli MRiRW i KOWR podczas konferencji naukowej 20 listopada 2019 r. w Poznaniu. Podkreślano wtedy, że istotę tego obowiązku należy łączyć z koniecznością prowadzenia gospodarstwa rolnego, nie zaś z samym nabyciem nieruchomości rolnej. Powinność prowadzenia gospodarstwa rolnego przez nabywcę występuje wówczas, gdy posiada on takie gospodarstwo ${ }^{48}$. Warto dodać, że ustawodawca w u.k.u.r. posługuje się nie tylko określeniem „prowadzenie gospodarstwa rolnego” czy „działalaność rolnicza”, lecz także „wykorzystywanie nieruchomości rolniczej na cele rolnicze”.

Zakaz zbywania i oddawania w posiadanie w ciągu 5 lat od nabycia odnosi się również do nieruchomości rolnych o powierzchni mniejszej niż 1 ha (z wyjątkami określonymi w art. $2 \mathrm{~b}$ ust. 4 , czyli np. nabytej w wyniku dziedziczenia oraz działu spadku lub zapisu windykacyjnego lub o powierzchni mniejszej niż 1 ha, położonej w granicach administracyjnych miasta).

Kolejne istotne dla notariuszy zagadnienie to przeniesienie własności nieruchomości rolnych będących $\mathrm{w}$ dzierżawie $\mathrm{w}$ aspekcie prowadzenia gospodarstwa rolnego na tych gruntach. Przepisy Kodeksu cywilnego o dzierżawie nie normują wpływu zbycia przedmiotu dzierżawy osobie trzeciej na stosunek dzierżawy. Należy zatem odwołać się tu do przepisów o najmie ${ }^{49}$. Według art. $678 \S 1 \mathrm{w}$ związku z art. 694 k.c. W razie zbycia rzeczy dzierżawionej

${ }^{48}$ Wypowiedzi przedstawicieli MRiRW i KOWR w czasie panelu dyskusyjnego na konferencji naukowej „Ustawa o kształtowaniu ustroju rolnego w teorii i praktyce”, Wydział Prawa i Administracji UAM, Poznań 20 listopada 2019 r. Tak też np. J. Bieluk, Ustawa o ksztattowaniu ustroju..., komentarz do art. 2b (pkt 7), Legalis nr 2019. Zob. też Często zadawane pytania, http:// www.kowr.gov.pl/ukur/zgody-na-nabycie-nieruchomosci-rolnych/czesto-zadawane-pytania [dostęp: 30.11.2019].

${ }^{49}$ Na gruncie umowy najmu J. Panowicz-Lipska, Najem, w: J. Panowicz-Lipska (red.), System Prawa Prywatnego. Prawo zobowiazań - część szczegółowa, t. 8, Warszawa 2004, s. 46 i n. 
w czasie trwania dzierżawy nabywca wstępuje w stosunek dzierżawy na miejsce zbywcy. Oznacza to, że ex lege nabywca staje się podmiotem trwającego stosunku prawnego i przejmuje wszelkie obowiązki oraz uprawnienia zbywcy (wydzierżawiającego). Na wstąpienie nabywcy w stosunek dzierżawy zgoda dzierżawcy nie jest wymagana, mimo zmiany podmiotu dzierżawa pozostaje tym samym zobowiązaniem ${ }^{50}$.

Problem powstaje także podczas przeniesienia własności nieruchomości rolnych będących w dzierżawie w aspekcie wymogu prowadzenia gospodarstwa rolnego, w skład którego weszła nabyta nieruchomość rolna, przez okres co najmniej 5 lat od dnia nabycia tej nieruchomości. W przypadku zbycia nieruchomości rolnej oddanej w dzierżawę następuje ciągłość dzierżawy. Pojawia się tu bardzo istotna dla notariuszy wątpliwość: czy możliwa jest sprzedaż lub darowizna nieruchomości rolnych będących w dzierżawie w kontekście obowiązku prowadzenia gospodarstwa rolnego na tych gruntach. W przypadku umowy dzierżawy zawartej na czas nieoznaczony możliwe jest jej wypowiedzenie. Natomiast z reguły nie jest to dopuszczalne w przypadku kontraktów zawartych na czas oznaczony (ewentualnie w trybie natychmiastowym lub gdy umowa na czas oznaczony dopuszcza jej wypowiedzenie). Widać tu sprzeczność regulacji prawnych. $Z$ jednej strony Kodeks cywilny przewiduje możliwość sprzedaży gruntów rolnych będących w dzierżawie, $\mathrm{z}$ drugiej zaś - wielu nabywców nie będzie w stanie wypełnić obowiązku z UKUR prowadzenia gospodarstwa rolnego. Od 26 czerwca 2019 r. wyróżnić należy dwie sytuacje.

Pierwsza to taka, gdy nie ma obowiązku osobistego prowadzenia gospodarstwa rolnego. Przykładowo: nieruchomość rolna ma powierzchnię mniejszą niż 1 ha i nie wchodzi w skład gospodarstwa rolnego oraz położona jest $\mathrm{w}$ granicach administracyjnych miasta. Nabywca nie ma wtedy obowiązku prowadzenia działalności rolniczej i nie obowiązuje go zakaz zbywania i oddawania w dzierżawę, co powoduje, że grunty może nadal uprawiać dzierżawca. Również osoby, które nabyły nieruchomości rolne w drodze dziedziczenia, mogą oddawać je w dzierżawę. Można także oddać nabyte nieruchomości rolne w dzierżawę osobom bliskim.

Druga sytuacja to nabycie nieruchomości rolnej o powierzchni 1 ha lub większej, gdy nabywca nieruchomości rolnej jest obowiązany prowadzić gospodarstwo rolne, w skład którego weszła nabyta nieruchomość rolna, przez okres co najmniej 5 lat od dnia nabycia przez niego tej nieruchomości. Powstaje pytanie, czy dzierżawiona nieruchomość weszła w skład gospodarstwa rolnego nabywcy, skoro stanowi składnik gospodarstwa rolnego dzierżawcy i jest

${ }^{50}$ C. Stempka-Jaźwińska, Umowa dzierżawy nieruchomości, Toruń 1981, s. 74 i n.; W. Pańko, Dzierżawa gruntów rolnych, Warszawa 1975, s. 110 i n. Na gruncie umowy najmu: J. Panowicz-Lipska, Najem, s. 46 i n. 
w posiadaniu dzierżawcy. $\mathrm{Z}$ art. $2 \mathrm{~b}$ ust. 2 u.k.u.r. wynika, że nieruchomość rolna $\mathrm{w}$ okresie 5 lat od nabycia nie może być zbyta ani oddana w posiadanie innym podmiotom. W świetle przepisu nabyta nieruchomość rolna co prawda nie może być oddana w posiadanie innym podmiotom, jednakże nieruchomość dzierżawiona jest $\mathrm{w}$ posiadaniu dzierżawcy przed i po zawarciu aktu notarialnego oraz wchodzi w skład jego gospodarstwa rolnego. Uzasadniona wydaje się interpretacja, że ewentualne osobiste prowadzenie gospodarstwa rolnego, w skład którego weszła nabyta nieruchomość rolna, przez okres co najmniej 5 lat, powinno liczyć się od czasu wygaśnięcia dzierżawy. Taka wykładnia celowościowa nie wynika bezpośrednio z przepisów, ale biorąc pod uwagę regulacje Kodeksu cywilnego oraz zachowanie trwałości gospodarowania, wydaje się uzasadniona. W praktyce jednak często stosowana jest interpretacja, że co do zasady (z wyjątkami wskazanymi powyżej) nabywca nieruchomości rolnej musi prowadzić gospodarstwo rolne od dnia nabycia tej nieruchomości. Taka wykładnia nie jest korzystna dla dzierżawców. Właściciel, który zamierza sprzedać grunt rolny będący w dzierżawie, podejmuje bowiem działania w celu wcześniejszego zakończenia dzierżawy (wykorzystując np. możliwości wypowiedzenia dzierżawy w trybie natychmiastowym).

Warto się zastanowić, jakie są konsekwencje sporządzenia aktu notarialnego obejmującego umowę przenoszącą własność nieruchomości rolnej będącej przedmiotem dzierżawy. Według art. 9 u.k.u.r. zbycie albo oddanie w posiadanie nieruchomości rolnej bez zgody Dyrektora Generalnego Krajowego Ośrodka, o której mowa w art. 2b ust. 3, jest nieważne. Jak zostało wyjaśnione, nie można oddać w posiadanie nieruchomości dzierżawcy, która była w jego posiadaniu w momencie zawarcia aktu notarialnego. Dlatego moim zdaniem w takiej sytuacji nie ma podstaw do stwierdzenia nieważności umowy dzierżawy. Kodeks cywilny pozwala na sprzedaż gruntów rolnych będących w dzierżawie, a u.k.u.r. nie wprowadziła przepisu uchylającego tę zasadę. Gdyby ustawodawca chciał ją zmodyfikować albo uchylić znalazłoby to odzwierciedlenie w ustawie. Tak się jednak nie stało.

Warto jeszcze nawiązać do wspomnianego art. 9 ustawy z 11 kwietnia 2003 r. Jeżeli nabywca nieruchomości rolnej np. przez okres co najmniej 5 lat: nie podjął lub zaprzestał prowadzenia gospodarstwa rolnego, a w przypadku osoby fizycznej - osobistego prowadzenia gospodarstwa rolnego, w skład którego weszła nabyta nieruchomość rolna, oddał w posiadanie nabytą nieruchomość rolną bez zgody Krajowego Ośrodka albo nie wykonuje zobowiązania, o którym mowa w art. 2a ust. 4 pkt 1 lit. b, pkt 2 lit. c lub pkt 3 lit. d (nabywca nieruchomości rolnej wskazany w decyzji Dyrektora Generalnego KOWR nie prowadzi działalności rolniczej na nabywanej nieruchomości rolnej) - Krajowy Ośrodek może wystąpić do sądu o nabycie własno- 
ści tej nieruchomości za zapłatą ceny odpowiadającej jej wartości rynkowej, określonej stosownie do przepisów o gospodarce nieruchomościami. Przepis ten stanowi istotne zagrożenie pozbawienia nabywców prawa własności nieruchomości rolnej w przypadku nierozpoczęcia czy zaprzestania prowadzenia gospodarstwa rolnego.

\section{Podsumowanie}

Po wejściu w życie u.k.u.r., a szczególnie nowelizacji z 14 kwietnia 2016 r., pojawiły się problemy interpretacyjne związane z pojęciem nieruchomości rolnej, gospodarstwa rolnego oraz działalności rolniczej, ale praktyka i doktryna starały się znaleźć rozwiązanie tej kwestii. Modyfikacje wprowadzone na podstawie nowelizacji z 26 kwietnia 2019 r. u.k.u.r. były w pewnym stopniu odpowiedzią na zgłaszane dylematy. Nie ulega wątpliwości, że występujące odmienne wykładnie wspomnianych pojęć nie służyły stabilizacji obrotu nieruchomościami rolnymi. Dlatego zmiany należy ocenić pozytywnie. Jednocześnie odnotować trzeba kwestie nadal dyskusyjne, np. wpływ zmiany przeznaczenia nieruchomości rolnych na cele nierolnicze na 5-letni obowiązek prowadzenia gospodarstwa rolnego. Zagadnienie konsekwencji modyfikacji planu miejscowego w odniesieniu do obowiązków właściciela nieruchomości rolnych powinno zostać uregulowane bezpośrednio w u.k.u.r. i uwzględniać to, że w planie tym można ustalić inny niż rolniczy sposób tymczasowego zagospodarowania gruntów.

Zmiana przeznaczenia nieruchomości rolnej prędzej czy później prowadzi do zaprzestania prowadzenia działalności rolniczej na tych gruntach i wyłączenie ich z produkcji rolniczej, co jest niekorzystne dla rolnictwa i produkcji żywności ${ }^{51}$. Dyskusyjne są także przypadki, w których w danej gminie nie ma planu zagospodarowania. Odwołanie się do pojęcia nieruchomości rolnej z Kodeksu cywilnego wywołuje problemy w praktyce. Notariusze czy sędziowie zmuszeni są w takiej sytuacji opierać ocenę stanu faktycznego na informacjach z ewidencji gruntów i budynków oraz oświadczeniach stron. Jak słusznie wskazuje się w literaturze, pomimo licznych wypowiedzi przedstawicieli dok-

${ }^{51} \mathrm{Na}$ marginesie można dodać, że planowanie przestrzenne wpływa w dużym stopniu na ochronę gruntów rolnych. Często kwestia ta nie jest w wystarczającym zakresie uwzględniana w czasie tworzenia projektu planu i potem jego uchwalania. Skoro ustawodawca podejmuje działania mające na celu ochronę nieruchomości rolnych, a szczególnie gospodarstw rodzinnych (art. 23 Konstytucji), to większą uwagę powinien poświęcić właśnie ustawie o planowaniu i zagospodarowaniu przestrzennym. Położenie nacisku tylko na samą u.k.u.r. nie zapewni wystarczającej ochrony. 
tryny i praktyków nie udało się dotąd wypracować wystarczająco precyzyjnego normatywnego pojęcia nieruchomości rolnej ${ }^{52}$.

Problemy w zakresie czynności notarialnych pojawiają się także co do gospodarstwa rolnego, np. gdy notariusz ma ustalić, czy poszczególne składniki stanowią lub mogą stanowić zorganizowaną całość gospodarczą. Ma to szczególne znaczenie w kontekście lasów, które mogą wchodzić w skład gospodarstwa rolnego, a w razie ich sprzedaży Lasom Państwowym może przysługiwać prawo pierwokupu. Podobnie jest z nieruchomościami rolnymi o powierzchni większej niż 1 ha, które mogą stanowić (lub nie) gospodarstwo rolne w świetle u.k.u.r. Notariusz może opierać się tylko i wyłącznie na oświadczeniu stron.

W praktyce wystąpił problem co do zbycia nieruchomości rolnych będących w dzierżawie, na co pozwalają przepisy Kodeksu cywilnego (art. $678 \S 1$ w związku z art. 694 k.c.). Regulacje u.k.u.r. stanowią, że nabywca jest zobowiązany do prowadzenia gospodarstwa rolnego, w skład którego weszła nabyta nieruchomość. Co do zasady przyjmuje się, że odnosi się ona także do nabywcy gruntów będących w dzierżawie. Zagadnienie to budzi jednak wątpliwości, więc ważna jest ingerencja ustawodawcy precyzująca tę kwestię. Regulacje prawne mogłyby np. stanowić, że osobiste prowadzenie gospodarstwa rolnego, w skład którego weszła nabyta nieruchomość rolna, przez okres co najmniej 5 lat, powinno liczyć się od czasu wygaśnięcia dzierżawy. Gdyby ustawodawca uznał, że taka zasada stwarza zagrożenie zawierania czy przedłużania umowy dzierżawy na dłuższe okresy (aby uniknąć konieczności podjęcia osobistego prowadzenia działalności rolniczej na nabytych gruntach), można rozważyć wprowadzenie dodatkowego długiego, np. 3-letniego, okresu wypowiedzenia dzierżawy (które następuje w momencie zawarcia umowy sprzedaży).

W przypadku kontraktów na czas oznaczony z datą pewną dzierżawcy powinno przysługiwać prawo do odszkodowania za wcześniejsze rozwiązanie umowy od wydzierżawiającego (sprzedawcy gruntu). Takie wypowiedzenie nie powinno przysługiwać, gdy dzierżawca np. realizuje program unijny i ma obowiązek przez 5 lat prowadzić na tych gruntach działalność rolniczą. Inną ewentualność stanowi zgoda KOWR czy sądu na sprzedaż nieruchomości rolnych będących w dzierżawie i możliwość kontynuacji takiej dzierżawy przez posiadacza zależnego do czasu wygaśnięcia kontraktu. Możliwych rozwiązań prawnych w tym zakresie jest sporo i istotne, aby ustawodawca uregulował tę kwestę bezpośrednio w u.k.u.r. Taka dysharmonia między przepisami k.c. a u.k.u.r. nie sprzyja stabilizacji obrotu nieruchomościami rolnymi ani nie ułatwia sporządzania aktów notarialnych.

${ }^{52}$ K. Marciniuk, Pojęcie nieruchomości rolnej..., s. 100 i n. 
W przypadku różnych interpretacji dotyczących u.k.u.r. korzystnym czasowym rozwiązaniem jest ogólnodostępna wykładnia MRiRW i KOWR oraz Krajowej Rady Notarialnej w sprawie stosowania u.k.u.r. w praktyce. Kwestie, które nadal wymagają wyjaśnienia, to przykładowo zakres przedmiotowy u.k.u.r. (w tym wpływ ostatecznej decyzji o warunkach zabudowy na zastosowanie u.k.u.r.), wskazanie osób objętych obowiązkiem prowadzenia gospodarstwa rolnego i zbywania gruntów w związku z wejściem w życie nowelizacji z 26 kwietnia 2019 r. (czy odnosi się do zstępnych, którzy nabywając nieruchomości, nie byli objęci takimi obowiązkami), sprawy związane ze współwłasnością nieruchomości rolnych, w tym majątkiem małżonków, oraz wskazanie, kiedy poszczególne składniki gospodarstwa rolnego stanowią lub mogą stanowić zorganizowaną całość gospodarczą (np. czy 10 ha gruntów rolnych bez budynków i inwentarza stanowi gospodarstwo rolne).

Należy jednak zaznaczyć, że w przypadku skierowania sporu na drogę sądową wyrok może się różnić od interpretacji wskazanych podmiotów. Dlatego najlepszym rozwiązaniem jest uchwalenie w przyszłości regulacji prawnych rozstrzygających pojawiające się nowe wątpliwości dotyczące definicji nieruchomości rolnej, gospodarstwa rolnego i działalności rolniczej. Asumptem do zmian przepisów mogą być właśnie wspólne stanowiska MRiRW, KOWR i Krajowej Rady Notarialnej, które identyfikują problemy oraz wskazują możliwości ich rozwiązania.

\title{
CONCEPT OF AGRICULTURAL PROPERTY, AGRICULTURAL HOLDING AND AGRICULTURAL ACTIVITY IN THE ACT ON SHAPING THE AGRICULTURAL SYSTEM - SELECTED ISSUES FROM NOTARIAL PRACTICE
}

\author{
Summary
}

The aim of the considerations is an attempt to solve problems related to the interpretation of the concepts of agricultural property, an agricultural holding and agricultural activity as defined in the Act on shaping the agricultural system experienced by notaries in their practice. After the entry of the Act into force, and especially after the amendment of 14 April 2016, there emerged interpretation problems related to the concept of agricultural property, an agricultural holding and agricultural activity, but the practice and doctrine strived to find interpretative solutions despite the difficulties. As a result, however, diverse interpretations of the concepts or terms in question did not serve the stability of the trading in agricultural property. The modifications introduced on the basis of the amendment of the Act of 26 April 2019 were to some extent a response to the dilemmas reported, and as such they must be assessed positively. At the same time, certain controversial issues remain, and example of which is the impact of a change from the designation of agricultural property for non-agricultural purposes into a 5-year obligation to operate an agricultural holding. 


\section{IL CONCETTO DI FONDO AGRICOLO, AZIENDA AGRICOLA E ATTIVITÀ AGRICOLA NELLA LEGGE SUL REGIME AGRICOLO: QUESTIONI SCELTE PROVENIENTI DALLA PRATICA NOTARILE}

\section{Riassunto}

L'articolo si propone di risolvere i problemi di interpretazione relativi al concetto di fondo agricolo, azienda agricola, attività agricola presenti nella legge sul regime agricolo nel contesto della pratica notarile. A seguito della sua entrata in vigore, e in particolare della revisione del 14 aprile 2016, si sono verificati problemi di interpretazione legati ai concetti menzionati, ai quali la pratica e la dottrina hanno cercato di ovviare. Le modifiche introdotte, basate sulla revisione del 26 aprile 2019, hanno dato, almeno in parte, una risposta ai dilemmi segnalati. Non vi è dubbio che le varie interpretazioni in circolazione non erano d'aiuto nel normalizzare la compravendita in oggetto. Pertanto, le modifiche andrebbero valutate positivamente, anche se le controversie continuano a sorgere. Ne è un esempio l'impatto, esercitato dalla modifica della destinazione d'uso dei fondi agricoli a fini non agricoli, sull'obbligo di svolgere un'attività agricola per la durata di 5 anni. 